\title{
Does the Nitrogen Rates, Methods and Times of Application Influences the Corn Nutrition and Yield?
}

\author{
Jéssica Vettorazzi ${ }^{1}$, Marcelo C. M. Teixeira Filho ${ }^{1}$, Fernando S. Galindo ${ }^{1}$, Elisângela Dupas ${ }^{1}$, \\ Élcio H. Yano ${ }^{1} \&$ Salatiér Buzetti ${ }^{1}$ \\ ${ }^{1}$ Department of Plant Health, Rural Engineering, and Soils, College of Engineering, Sao Paulo State University, \\ Ilha Solteira, SP, Brazil \\ Correspondence: Fernando S. Galindo, Department of Plant Health, Rural Engineering, College of Engineering, \\ and Soils, Sao Paulo State University (UNESP), Ilha Solteira, State of Sao Paulo, Brazil. Tel: 55-18-98120-8054. \\ E-mail: fs.galindo@yahoo.com.br
}

Received: September 25, 2018

Accepted: October 27, 2018 Online Published: December 15, 2018

doi:10.5539/jas.v11n1p350

URL: https://doi.org/10.5539/jas.v11n1p350

\begin{abstract}
Alternatives to reduce $\mathrm{N}$ losses in soil, increasing the nutrient utilization efficiency by the plant with increased grain yield are necessary for the adequate and sustainable management of this nutrient. In this context, the objective of this study was to evaluate the use of $\mathrm{N}$ rates at different times and in different methods of application, evaluating the nutritional status and corn grain yield in the Cerrado (Savannah) region. The study was conducted in Selvíria - MS, Brazil, in an Oxisol. The experimental design was a randomized complete block design with four replicates, arranged in a factorial scheme $6 \times 2 \times 2$, being: 6 rates of $\mathrm{N}(0,50,100,150,200$, $250 \mathrm{~kg} \mathrm{ha}^{-1}$ ), 2 times of application (at seeding or top-dressing) and 2 methods of application (surface or incorporated) with the urea source. The evaluations that were performed: leaf chlorophyll index (LCI), macro and micronutrients concentrations in leaf tissue ( $\mathrm{N}, \mathrm{P}, \mathrm{K}, \mathrm{Ca}, \mathrm{Mg}, \mathrm{S}, \mathrm{Cu}, \mathrm{Fe}, \mathrm{Mn}$ and $\mathrm{Zn}$ ), and corn grain yield. The $\mathrm{N}$ supply at sowing time provided higher levels of $\mathrm{K}, \mathrm{Ca}, \mathrm{Mg}, \mathrm{Fe}$ and $\mathrm{Zn}$ in leaf tissue, while nitrogen fertilization at the V4 stage provided greater LCI. The incorporation of urea into the soil provided higher LCI and $\mathrm{N}, \mathrm{P}$ and $\mathrm{K}$ foliar contents. The increase of $\mathrm{N}$ doses influenced positively the LCI, N, P, S, Cu, Fe, Mn and $\mathrm{Zn}$ foliar contents, and increased corn grain yield up to the dose of $164 \mathrm{~kg} \mathrm{ha}^{-1}$ of $\mathrm{N}$. The urea application to the surface is more interesting to the incorporated application due to the ease of application, cost, besides propitiating similar corn grain yield.
\end{abstract}

Keywords: Zea mays L., nitrogen fertilization, urea, nutrient leaf concentration, grain yield

\section{Introduction}

Corn is one of the oldest and most widespread crops in the world. Despite the technological advances available, the average Brazilian productivity is still very low, around 5,401 kg ha- ${ }^{-1}$ CONAB, 2017), which demonstrates the need to seek management techniques to obtain increased grain yield and, consequently, to guarantee profits to the producer (Galindo et al., 2016).

In order to obtain high corn grain yield it is necessary to apply high rates of nitrogen $(\mathrm{N})$, as the soils do not usually supply the crop demand along its cycle (Galindo et al., 2017). In non-legume crops, nitrogen fertilization represents one of the highest costs of the production process (Nunes et al., 2015). Wheat, corn and rice crops consume approximately $60 \%$ of the total nitrogen fertilizer produced in the world (Espíndula et al., 2014). Therefore, the management of nitrogen fertilization is performed in order to ensure high productivity and depending on the $\mathrm{N}$ dynamics on soils, high $\mathrm{N}$ rates are added, which burdens the cost of production of farmers (Teixeira Filho et al., 2014).

Traditionally, annual crops receive only a fraction of the total $\mathrm{N}$ rate they need at sowing, and the remainder is applied in the interlining at times of greatest demand (Kaneko et al., 2015). This is principally due to three factors: low initial nutritional requirement, possibility of losses due to several factors such as leaching, volatilization, immobilization, besides the high salt content of nitrogen fertilizers (Mota et al., 2015).

The time of $\mathrm{N}$ application is one of the most discussed aspects in the management of nitrogen fertilization in grasses under no-tillage system, and since in the first years of adoption of this system the initial lack of $\mathrm{N}$ may 
occur of immobilization caused by the microbial decomposition of the residues of the predecessor crop (Teixeira Filho et al., 2010). Thus, in some cases, the anticipation of nitrogen fertilization, in relation to conventional recommendations or, even, in relation to crop sowing, may be more efficient in increasing grain yield (Nascente et al., 2011). However, there is a need for further studies, for the corn crop in regions with dry winter and controlled irrigation.

The $\mathrm{N}$ can be applied to the soil by different methods, being the most used the haul on the surface of the soil or incorporated in lines. When the $\mathrm{N}$ source used is urea, the most commonly used in agriculture, and no rainfall occurs in the first few days after application, soil incorporation may be important to minimize ammonia $\left(\mathrm{N}-\mathrm{NH}_{3}\right)$ formation and release to the atmosphere. Lara Cabezas et al. (2000) observed higher losses of $\mathrm{N}_{-} \mathrm{NH}_{3}$ with urea source when it was applied at the soil surface compared to its incorporation into the soil in corn crop. These authors estimated that there may be a reduction in corn grain yield due to the volatilization of $\mathrm{N}^{-\mathrm{NH}_{3}}$ in the proportion of $10 \mathrm{~kg} \mathrm{ha}^{-1}$ of grains for each $1 \%$ of $\mathrm{N}$ volatilized.

However, in most studies of times and methods of $\mathrm{N}$ application using urea as a source, even though some benefits have been observed, an increase in corn grain yield has not always been verified. Further experiments of this type should be performed to evaluate the effect on plant nutrition. In addition, there are still few studies that define the best time and form of $\mathrm{N}$ application associated with the best dose, aiming at an adequate management of nitrogen fertilization, reducing losses and moving towards a more sustainable agriculture.

The hypothesis of this study presupposes that the moment and the form of nitrogen application associated to $\mathrm{N}$ rates can increase the efficiency of the nitrogen fertilization and nutrition of corn plants, with a positive effect on grain yield. The objective of this study was to evaluate the effect of $\mathrm{N}$ rates at different times (sowing or top-dressing) and different methods of application (surface or incorporated) using urea as source, evaluating macro and micronutrients concentrations in leaf tissue, leaf chlorophyll index and corn grain yield in Cerrado (Savannah) region.

\section{Methods}

\subsection{Field Sites and Material Description}

The study was carried out at the Fazenda de Ensino, Pesquisa e Extensão (FEPE) at the Faculty of Engineering of Ilha Solteira, São Paulo State University (FEIS/UNESP), in the municipality of Selvíria, MS, Brazil, located at the geographic coordinates $22^{\circ} 22^{\prime}$ latitude $\mathrm{S}$ and $51^{\circ} 22^{\prime} \mathrm{W}$ longitude, with an altitude of $335 \mathrm{~m}$ (Figure 1).

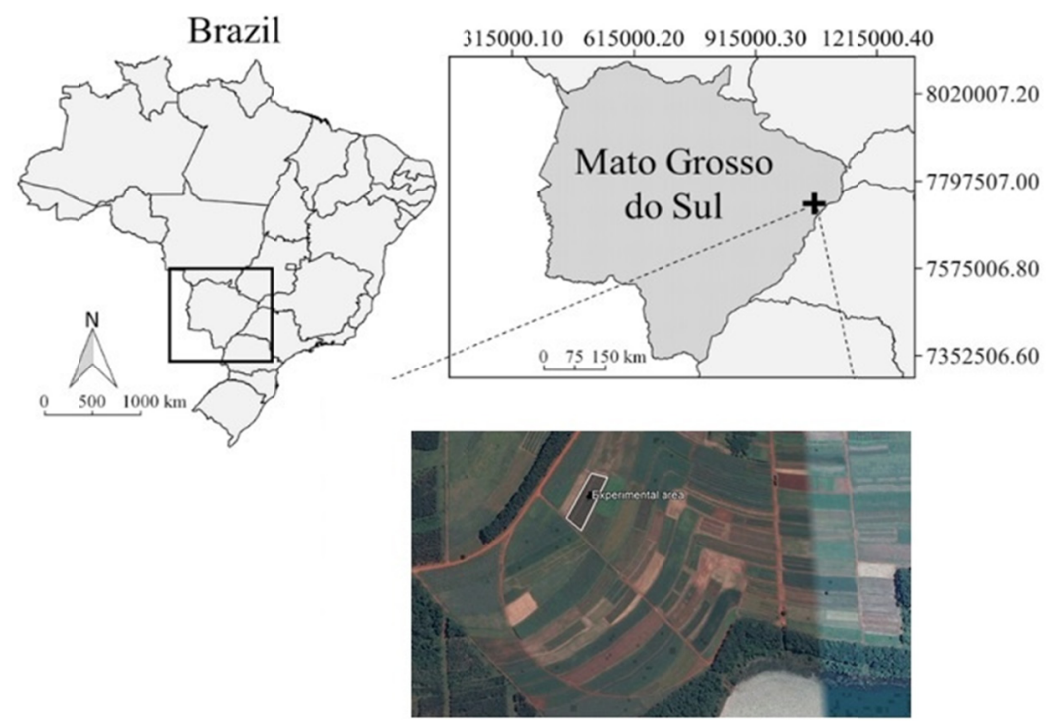

Figure 1. Study area located at Selvíria, Mato Grosso do Sul, Brazil $\left(20^{\circ} 22^{\prime} \mathrm{S}, 51^{\circ} 22^{\prime} \mathrm{W}\right.$, altitude of $\left.335 \mathrm{~m}\right)$

The soil of the experimental area was classified as an Oxisol, clay texture, according to Embrapa (2013). The study was conducted under field conditions and no-tillage system, irrigated by sprinkling, by means of a central pivot with a water depth of approximately $14 \mathrm{~mm}$ and with an irrigation interval of 72 hours system. The history of the area was with annual crop cultivation more than 27 years, and with the last 10 years being in no-tillage 
system, the last crop year being fallow. The granulometric analysis (depth of 0-0.20 m) presented the following results: 433, 471 and $90 \mathrm{~g} \mathrm{~kg}^{-1}$ of clay, sand and silt, respectively.

According to Köppen's classification, the climate is the fundamental type Aw (tropical humid with a rainy season in the summer and dryness in the winter), and the annual average temperature of $23.5^{\circ} \mathrm{C}$, average annual rainfall of $1370 \mathrm{~mm}$, with relative humidity average annual air temperature between 70 and $80 \%$. Figure 2 shows the climatic conditions during the study.

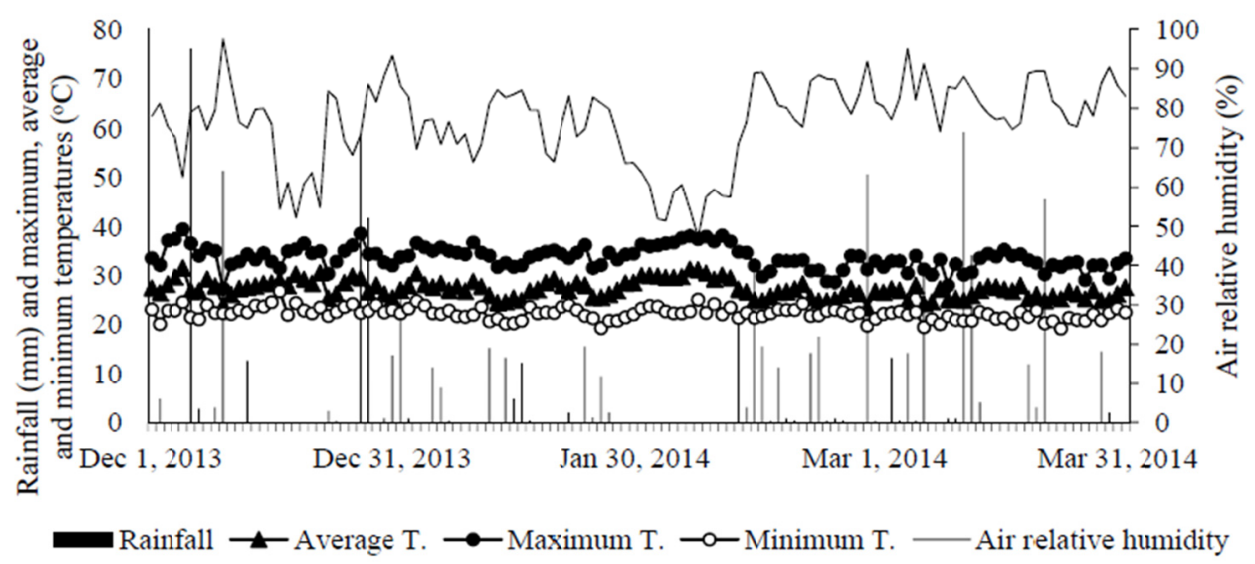

Figure 2. Rainfall, air relative humidity, and maximum, average, and minimum temperature obtained from the weather station located on the Education and Research Farm of FE/UNESP during corn cultivation in the period of December 2013 to April 2014

The soil chemical attributes in the arable layer determined before the installation of corn crop, in September of 2013 presented the following results: $10 \mathrm{mg} \mathrm{dm}^{-3}$ of $\mathrm{P}$ (resin); $5 \mathrm{mg} \mathrm{dm}^{-3}$ of S-SO $\mathrm{SO}_{4} 22 \mathrm{~g} \mathrm{dm}^{-3}$ O.M (Organic Mater); $5.3 \mathrm{pH}\left(\mathrm{CaCl}_{2}\right) ; \mathrm{K}, \mathrm{Ca}, \mathrm{Mg}, \mathrm{H}+\mathrm{Al}=2.4 ; 21.0 ; 18.0$ and $28.0 \mathrm{mmol}_{\mathrm{c}} \mathrm{dm}^{-3}$, respectively; $\mathrm{Cu}, \mathrm{Fe}, \mathrm{Mn}, \mathrm{Zn}$ $(\mathrm{DTPA})=3.2 ; 22.0 ; 24.2$ and $1.2 \mathrm{mg} \mathrm{dm}^{-3}$, respectively; $0.16 \mathrm{mg} \mathrm{dm}^{-3} \mathrm{~B}$ (hot water), CEC (cation exchange capacity) $51.58 \mathrm{mmol}_{\mathrm{c}} \mathrm{dm}^{-3}$ and $60 \%$ base saturation according to methodology proposed by Raij et al. (2001),

\subsection{Experimental Design}

The experimental design was a randomized complete block design with four replicates arranged in a factorial scheme: $6 \times 2 \times 2: 6$ rates of $\mathrm{N}\left(0,50,100,150,200\right.$ and $\left.250 \mathrm{~kg} \mathrm{ha}^{-1}\right), 2$ methods of application (surface without incorporation and applied in corn spacing and incorporated-mechanically incorporated in the corn spacing) and 2 application times (totally in sowing and top-dressing, in a single application without splitting). The treatments were mechanically applied and the nitrogen source was granular urea (45\% $\mathrm{N})$. The dimensions of the plots were $10 \mathrm{~m}$ in length with four useful lines and spacing between plants of $0.45 \mathrm{~m}$, and expected population of 66 thousand plants per hectare.

\subsection{Crop Development}

The desiccation of the area was performed 20 days before sowing with the herbicides glyphosate $\left(1800 \mathrm{~g} \mathrm{ha}^{-1} \mathrm{of}\right.$ active ingredient-a.i.) and 2,4-D (670 $\mathrm{g} \mathrm{ha}^{-1}$ of a.i.), and five days before sowing the straw was managed by triton to facilitate cultural management. The sowing of the triple corn hybrid DKB 350 PRO (cartridge caterpillar resistant-Spodoptera frugiperda) was performed mechanically, on 12/16/2013. Afterwards, the area was irrigated to promote seed germination. Seedlings emerged five days after sowing.

In the sowing fertilization, 112 and $64 \mathrm{~kg} \mathrm{ha}^{-1}$ of $\mathrm{P}_{2} \mathrm{O}_{5}$ and $\mathrm{K}_{2} \mathrm{O}$ as triple superphosphate and potassium chloride were applied, respectively, based on the soil analysis and corn yield expectation. Nitrogen fertilization was carried out according to the treatments mentioned previously, and always between corn lines, at the time of sowing, or in corn V4 stage (01/08/2014). When incorporated into the soil, the urea was deposited at a depth of about five to seven $\mathrm{cm}$ above ground level. The experimental area was irrigated by sprinkling, by means of central pivot on the following day of the top-dressing fertilization. 
For weed control, the herbicides tembotrione $\left(84 \mathrm{~g} \mathrm{ha}^{-1}\right.$ of a.i.) and atrazine (1000 $\mathrm{g} \mathrm{ha}^{-1}$ of a.i.) were applied, plus the addition of vegetable oil (720 $\mathrm{g} \mathrm{ha}^{-1}$ of a.i.) as adjuvant in the herbicide syrup in post-emergence, at stage V2. Pest and disease control was not necessary.

Corn was harvested manually and individually per experimental unit on 18/04/2014, 118 days after plant emergence. The material was then dried in full sun and mechanically trodden.

\subsection{Analytical Procedures}

During the conduction of the experiment, the following evaluations were performed:

(a) Leaf chlorophyll index (LCI), measured indirectly by means of digital chlorophyllometer CFL 1030 Falker, in 8 leaves of the main ear insertion, at the time of corn feminine flowering;

(b) Foliar concentration analysis of macronutrients $(\mathrm{N}, \mathrm{P}, \mathrm{K}, \mathrm{Ca}, \mathrm{Mg}$ and $\mathrm{S})$ and micronutrients $(\mathrm{Cu}, \mathrm{Fe}, \mathrm{Mn}$ and $\mathrm{Zn}$ ), according to Malavolta et al. (1997), by collecting the middle third of ten leaves of the main spike at the female flowering stage according to the methodology described in Cantarella et al. (1997);

and (c) Grain yield, determined by harvesting the spikes contained in $10 \mathrm{~m}$ of each of the four central rows portion, at physiological maturity stage (R6). The material was subjected to drying in full sun and after the mechanical track, the grains were quantified and the data transformed in $\mathrm{kg} \mathrm{ha}^{-1}$, at $13 \%$ (wet basis).

\subsection{Statistical Analysis}

The evaluated variables were submitted to analysis of variance (test F) and the means of the $\mathrm{N}$ methods and times of application were compared by the Tukey test at 5\% of probability. Polinomial regression analysis was used for N rates. For statistical analysis, the SISVAR program was used (Ferreira, 2011).

\section{Results and Discussion}

The times of $\mathrm{N}$ application influenced the concentrations of $\mathrm{K}, \mathrm{Ca}, \mathrm{Mg}, \mathrm{Fe}, \mathrm{Zn}$ in leaf tissue and LCI (Table 1). The $\mathrm{N}$ application at the time of sowing provided higher concentrations of these nutrients, however, the application in top-dressing provided higher LCI (Table 1). 
Table 1. N, P, K Ca, Mg, S, Cu, Fe, Mn and $\mathrm{Zn}$ concentration in foliar tissue, LCI and corn grain yield as a function of times, methods of application and N rates. Selvíria, MS, Brazil, 2013/2014

\begin{tabular}{|c|c|c|c|c|c|c|}
\hline & $\mathrm{N}$ & $\mathrm{P}$ & $\mathrm{K}$ & $\mathrm{Ca}$ & $\mathrm{Mg}$ & $\mathrm{S}$ \\
\hline & \multicolumn{6}{|c|}{ 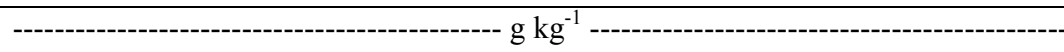 } \\
\hline \multicolumn{7}{|c|}{ (25) } \\
\hline Seedling & $29.20 \mathrm{a}$ & $2.99 \mathrm{a}$ & $18.55 \mathrm{a}$ & $2.47 \mathrm{a}$ & $1.41 \mathrm{a}$ & $3.90 \mathrm{a}$ \\
\hline Top-dressing & $28.73 \mathrm{a}$ & $3.09 \mathrm{a}$ & $16.52 \mathrm{~b}$ & $2.24 \mathrm{~b}$ & $1.23 \mathrm{~b}$ & $3.89 \mathrm{a}$ \\
\hline \multicolumn{7}{|c|}{ Methods of application } \\
\hline Surface & $28.45 \mathrm{~b}$ & $2.94 \mathrm{~b}$ & $17.50 \mathrm{~b}$ & $2.42 \mathrm{a}$ & $1.43 \mathrm{a}$ & $3.90 \mathrm{a}$ \\
\hline Incorporated & $29.48 \mathrm{a}$ & $3.14 \mathrm{a}$ & $17.58 \mathrm{a}$ & $2.29 \mathrm{a}$ & $1.21 \mathrm{~b}$ & $3.89 \mathrm{a}$ \\
\hline L.S.D. $(5 \%)$ & 0.96 & 0.13 & 1.16 & 0.17 & 0.11 & 0.23 \\
\hline \multicolumn{7}{|c|}{ N rates $\left(\mathrm{kg} \mathrm{ha}^{-1}\right)$} \\
\hline 0 & 25.67 & 2.80 & 17.67 & 2.53 & 1.33 & 3.50 \\
\hline 50 & 27.84 & 2.93 & 16.25 & 2.36 & 1.36 & 3.68 \\
\hline 100 & 28.43 & 2.94 & 17.33 & 2.27 & 1.31 & 3.88 \\
\hline 150 & 29.10 & 3.08 & 17.50 & 2.26 & 1.32 & 3.98 \\
\hline 200 & 31.15 & 3.20 & 18.33 & 2.49 & 1.38 & 4.29 \\
\hline 250 & 31.63 & 3.32 & 18.17 & 2.27 & 1.25 & 4.06 \\
\hline \multirow[t]{3}{*}{ C.V. $(\%)$} & 6.95 & 9.25 & 13.91 & 15.49 & 16.71 & 12.53 \\
\hline & $\mathrm{Cu}$ & $\mathrm{Fe}$ & $\mathrm{Mn}$ & $\mathrm{Zn}$ & ICF & Grain Yield \\
\hline & \multicolumn{5}{|c|}{ 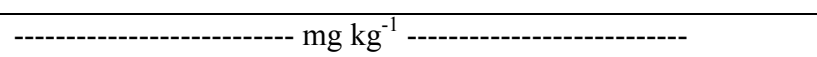 } & --- $\mathrm{kg} \mathrm{ha}^{-1}---$ \\
\hline \multicolumn{7}{|c|}{ Times of application } \\
\hline Seedling & $20.50 \mathrm{a}$ & $119.30 \mathrm{a}$ & $76.16 \mathrm{a}$ & $25.25 \mathrm{a}$ & $61.66 \mathrm{~b}$ & $8464 \mathrm{a}$ \\
\hline Top-dressing & $18.61 \mathrm{a}$ & $111.75 \mathrm{~b}$ & $70.00 \mathrm{a}$ & $23.05 \mathrm{~b}$ & $64.10 \mathrm{a}$ & $8617 \mathrm{a}$ \\
\hline \multicolumn{7}{|c|}{ Methods of application } \\
\hline Surface & $19.27 \mathrm{a}$ & $116.13 \mathrm{a}$ & $69.97 \mathrm{a}$ & $24.36 \mathrm{a}$ & $61.89 \mathrm{~b}$ & $8697 \mathrm{a}$ \\
\hline Incorporated & $19.83 \mathrm{a}$ & $114.91 \mathrm{a}$ & $76.19 \mathrm{a}$ & $23.94 \mathrm{a}$ & $63.87 \mathrm{a}$ & $8385 \mathrm{a}$ \\
\hline L.S.D. $(5 \%)$ & 2.51 & 6.40 & 9.11 & 1.42 & 1.68 & 322 \\
\hline \multicolumn{7}{|c|}{ N rates $\left(\mathrm{kg} \mathrm{ha}^{-1}\right)$} \\
\hline 0 & 17.33 & 108.00 & 55.00 & 21.00 & 51.45 & 6460 \\
\hline 50 & 16.67 & 107.83 & 63.75 & 23.00 & 62.45 & 8597 \\
\hline 100 & 20.33 & 110.42 & 63.42 & 22.83 & 65.18 & 9056 \\
\hline 150 & 20.67 & 117.00 & 71.50 & 25.17 & 65.44 & 9256 \\
\hline 200 & 21.00 & 121.17 & 91.33 & 26.58 & 66.05 & 8947 \\
\hline 250 & 21.33 & 128.75 & 93.50 & 26.33 & 66.72 & 8929 \\
\hline C.V. $(\%)$ & 27.10 & 11.68 & 26.28 & 12.37 & 6.57 & 9.26 \\
\hline
\end{tabular}

Note. Means followed by the same letter in the column do not differ by Tukey test at 5\% probability.

The $\mathrm{N}$ availability in an initial development period of corn crop may have led to a greater development of the root system in the early stages of corn, and with higher volume of soil explored, higher nutrient uptake may have occurred, especially K, Ca, Mg, Fe and Zn, corroborating with Galindo et al. (2016), who verified an increase in nutrient concentration in foliar tissue as a function of nitrogen fertilization management.

Regarding the LCI, the highest values obtained in the top-dressing application can be explained due to the greater proximity of the fertilization with the leaves collection for nutritional diagnosis. It is worth mentioning that some researchers showed a positive relationship between chlorophyll reading and chlorophyll content in corn leaf and between leaf chlorophyll content and $\mathrm{N}$ content in plants (Maestrelo et al., 2014), evidencing that the increase in $\mathrm{N}$ provides higher content of chlorophyll in leaf tissue and thus a higher rate of photosynthesis, since this nutrient participates in the composition of the chlorophyll molecule (Noor, 2017).

Although the time of $\mathrm{N}$ application influenced nutrient concentration and LCI, there was no difference in $\mathrm{N}$ leaf concentration and corn grain yield (Table 1). Santos et al. (2010), studying N application times (15 days before sowing, sowing and at V4 stage) also did not verify difference in N leaf concentration. Similarly, Kaneko et al. 
(2010), working with urea at the dose of $120 \mathrm{~kg} \mathrm{ha}^{-1}$ also did not verify difference between the $\mathrm{N}$ application in sowing and at top-dressing in corn crop.

Regarding the form of application, when the treatments were incorporated in the soil, the concentrations of N, P, $\mathrm{K}$ in leaf tissue and LCI were higher (Table 1). However, for the Mg concentration, the inverse effect was verified, where the treatments applied on the surface provided higher concentration of this nutrient (Table 1).

These results indicate that there were probably lower $\mathrm{N}$ losses by ammonia volatilization with urea incorporation into the soil, with higher $\mathrm{N}$ utilization as a function of the higher $\mathrm{N}$ concentration in leaf tissue and LCI and in the absorption of the primary macronutrients $\mathrm{P}$ and $\mathrm{K}$, however, as well as for $\mathrm{N}$ times of application, was not sufficient to influence grain yield (Table 1), corroborating with Kaneko et al. (2015), working with surface or incorporated application of urea, verified that there was no influence of the $\mathrm{N}$ form of application on corn grain yield.

For the $\mathrm{N}$ rates applied, there was an influence on $\mathrm{N}, \mathrm{P}, \mathrm{S}, \mathrm{Cu}, \mathrm{Fe}, \mathrm{Mn}$ and $\mathrm{Zn}$ contents in leaf tissue, in $\mathrm{LCI}$ and corn grain yield in a positive way, adjusted to the linear function increasing for the nutrient concentrations (Table 1 , Figures 3 and 4) and adjustment to the quadratic function until the approximate doses of 196.5 and $164.3 \mathrm{~kg}$ $\mathrm{ha}^{-1}$ of $\mathrm{N}$ for LCI and corn grain yield, respectively. The obtained results demonstrate the importance of $\mathrm{N}$ in plant nutrition and absorption of nutrients as reported by Galindo et al. (2016). Similar results were obtained Soratto et al. (2010) and Costa et al. (2012), which verified a linear and positive effect of $\mathrm{N}$ rates affecting $\mathrm{N}$ leaf content up to the rates of 120 and $200 \mathrm{~kg} \mathrm{ha}^{-1}$ of $\mathrm{N}$.
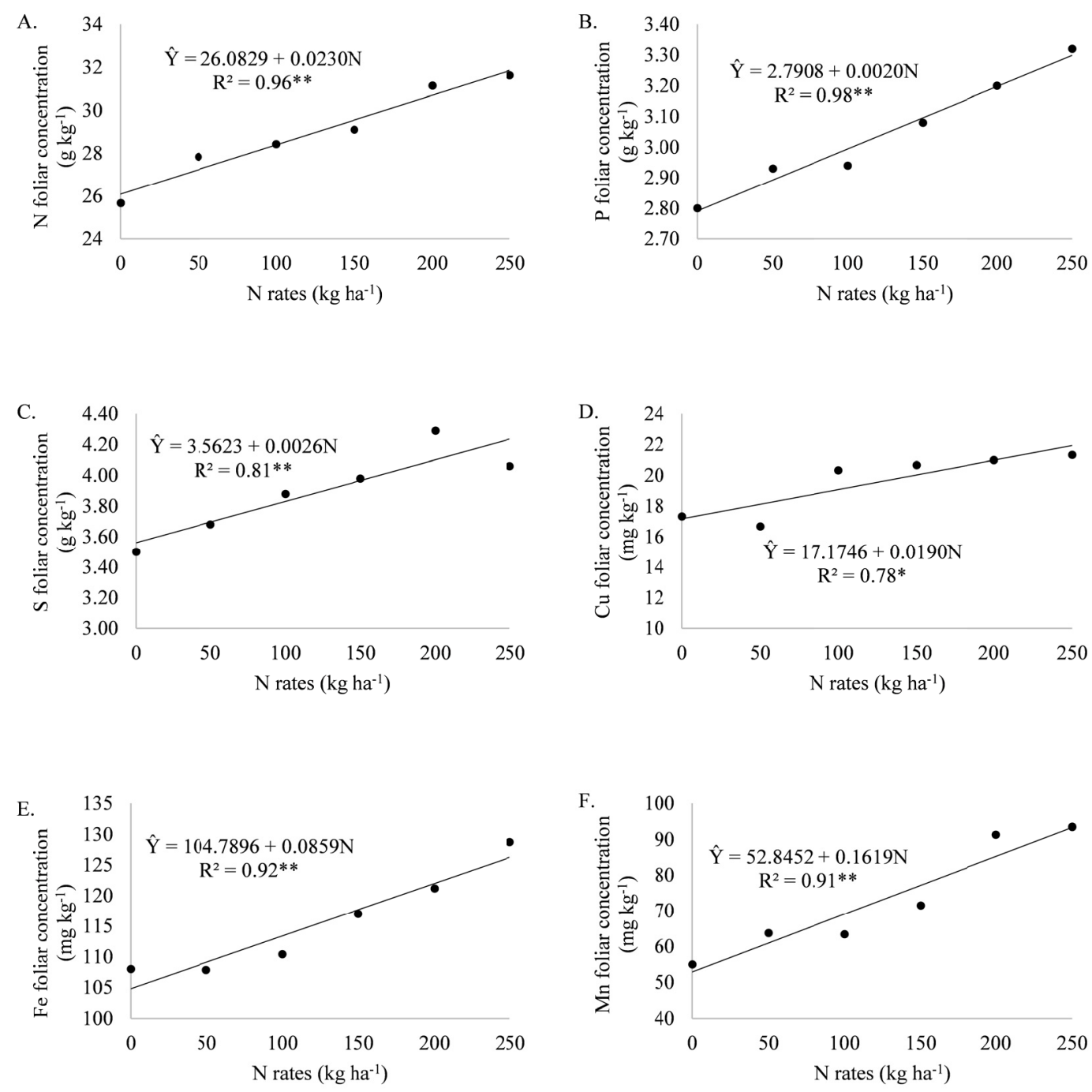

Figure 3. N (A), P (B), S (C), Cu (D), Fe (E) and Mn (F) concentrations in leaf tissue as a function of $\mathrm{N}$ rates 

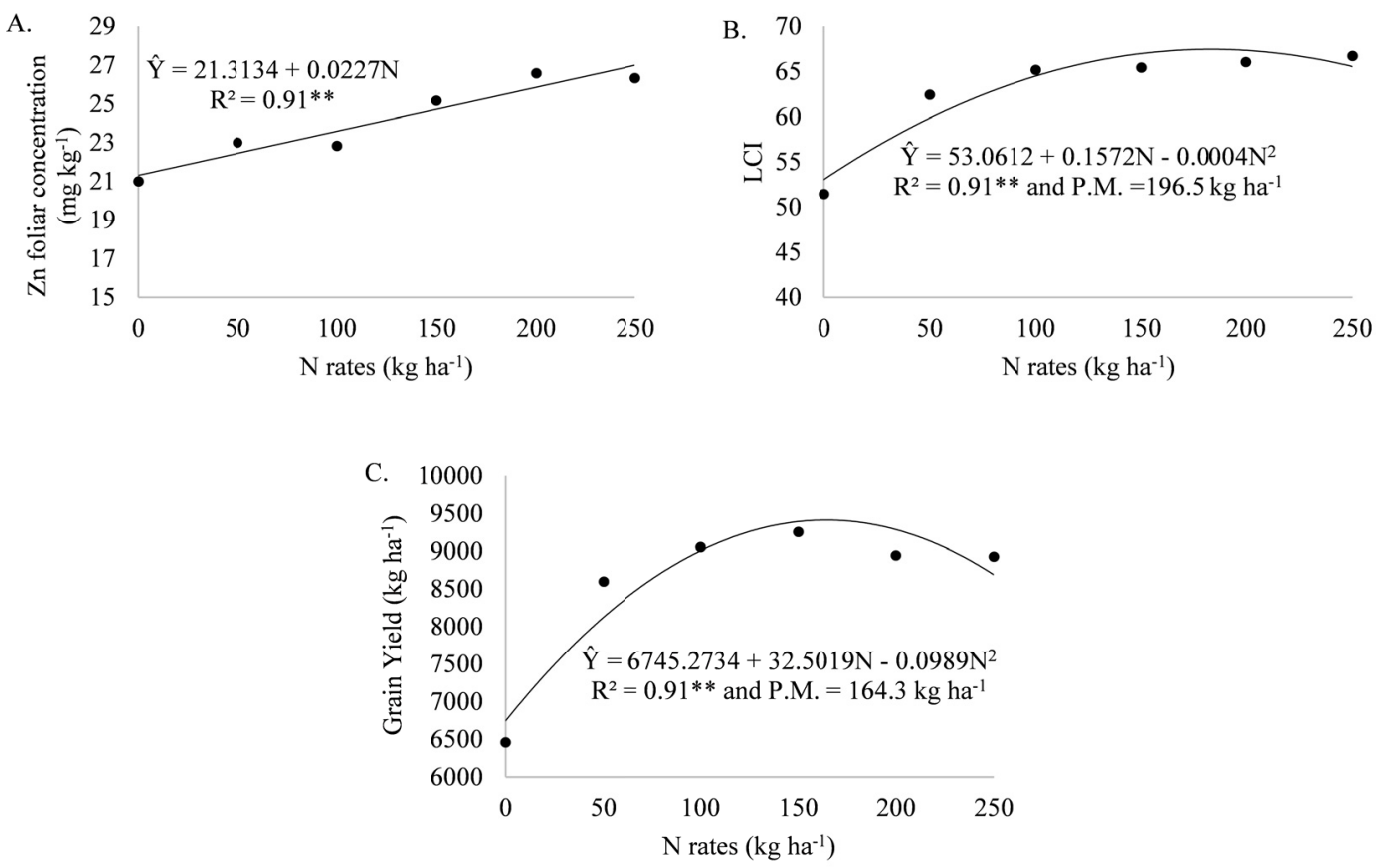

Figure 4. $\mathrm{Zn}$ concentration in leaf tissue (A), LCI (B) and corn grain yield (C) as a function of $\mathrm{N}$ rates

$\mathrm{N}$ is the nutrient that most interferes in the development and productivity of crops, especially grasses (Noor, 2017). This nutrient is found in higher concentrations in plant tissues and grains, besides being the nutrient required in greater quantity by the corn crop (Liu et al., 2017, Sun et al., 2017). Thus, the higher availability of this nutrient to the plants may have favored the development of the root system, which, when exploring a larger volume of soil, absorbed larger amounts of nutrients, such as $\mathrm{N}, \mathrm{P}, \mathrm{S}, \mathrm{Cu}, \mathrm{Fe}, \mathrm{Mn}$ and $\mathrm{Zn}$ as verified in the present study, and water, besides increasing LCI, reflecting the increase in grain yield, since $\mathrm{N}$ is involved in the synthesis of proteins, chlorophyll, coenzymes, nucleic acids and secondary metabolites (Marschner, 2012).

In relation to the $P$ concentration in leaf tissue, the results obtained corroborate with Kappes et al. (2013a), which verified a linear increase in the $\mathrm{P}$ concentration with the increase of $\mathrm{N}$ rates in top-dressing (up to $120 \mathrm{~kg} \mathrm{ha}^{-1}$ ). The probable higher development of root system promoted by the nitrogen fertilization favors the contact between the roots and the phosphate in the soil by diffusion, leading to greater nutrient absorption, with a reflection on the $\mathrm{P}$ foliar concentration.

For the $\mathrm{S}$ concentration in leaf tissue, the results obtained are similar to those verified by Soratto et al. (2010), who verified increase of $\mathrm{S}$ concentration with increase of applied $\mathrm{N}$ rates. However, the relationships between $\mathrm{N}$ and $\mathrm{S}$ concentrations obtained in the present study (approximate value of 8 to 1) were below the range indicated by Arnon (1975) to promote maximum dry matter and protein production, ranging from 12 to 15 for 1 , which could negatively influence the corn crop development.

The $\mathrm{K}$ concentration in leaf tissue was not influenced by the $\mathrm{N}$ rates in top-dressing, ratifying the results observed by Kappes et al. (2013a), which did not verify the influence of $\mathrm{N}$ rates on the concentration of this nutrient in corn crop.

In relation to the cationic micronutrients concentrations in leaf tissue, $\mathrm{Cu}, \mathrm{Fe}$ and $\mathrm{Mn}$ are generally found in high levels in Oxisols (Gazola et al., 2017), and may have been favored by acidification caused by nitrogen fertilization, mainly in the topsoil (Costa et al., 2008), which may have afforded higher availability, and consequently, increase the absorption of these cationic micronutrients, including also $\mathrm{Zn}$, which although not found in high levels in tropical soils, probably have their absorption favored by the acidification propitiated by nitrogen fertilization.

In a similar way to the results obtained for LCI, it is observed in the literature some research involving $\mathrm{N}$ rates application in corn crop, positively influencing this variable, as in the study of Costa et al. (2012), with rates up to $200 \mathrm{~kg} \mathrm{ha}^{-1}$ using urea, Kappes et al. (2013b), using 0, 60, 90 and $120 \mathrm{~kg} \mathrm{ha}^{-1}$ of N, in the form of urea applied in top-dressing and Maestrelo et al. (2014), with application of $96 \mathrm{~kg} \mathrm{ha}^{-1}$ of $\mathrm{N}$ in corn crop. However, it is worth noting that the values found for LCI are relatively high, even in the control plots (65.17 at the mean of the 
applied rates and 51.45 in the absence of nitrogen fertilization). Costa et al. (2012), Kappes et al. (2013b) also found ICF values ranging from 39.9 to 71.2 and 51.1 and 68.5 , respectively.

With respect of grain yield, several studies have reported a positive effect of increasing $\mathrm{N}$ rates application in corn grain yield (Souza et al., 2011; Goes et al., 2004; Kappes et al., 2014, Dathe et al., 2016, Galindo et al., 2016, Zhou et al., 2017), reinforcing the results obtained. Thus, the highest corn grain yield were obtained when $\mathrm{N}$ was supplied in high rates, up to the dose of $164 \mathrm{~kg} \mathrm{ha}^{-1} \mathrm{of} \mathrm{N}$. This can be explained by the high $\mathrm{N}$ demand of the hybrid studied and the fact that corn crop was in succession to a fallow area, whose spontaneous vegetation presented high $\mathrm{C} / \mathrm{N}$ ratio, and the desiccation and mechanical disintegration were performed with less than 15 days before corn sowing, evidencing the effect of $\mathrm{N}$ immobilization in straw.

According to Cantarella et al. (1997), the appropriate range for $\mathrm{N}, \mathrm{P}, \mathrm{K}, \mathrm{Ca}, \mathrm{Mg}, \mathrm{S}, \mathrm{Cu}, \mathrm{Fe}, \mathrm{Mn}$ and $\mathrm{Zn}$ in leaf tissue are, respectively, 27-35; 2.0-4.0;17.0-35.0; 2.5-8.0;1.5-5.0;1.5-3.0 g kg-1 and $6.0-20.0 ; 30.0-250.0$; 20.0-200.0 and 15.0-100.0 mg kg-1, therefore, it is verified that the contents of $\mathrm{N}$ (with the exception of the control), $\mathrm{P}, \mathrm{K}$ (except in the mean of treatments with top-dressing application), $\mathrm{Cu}, \mathrm{Fe}, \mathrm{Mn}$ and $\mathrm{Zn}$ in were adequate (Table 1). The leaf contents of $\mathrm{Ca}$ and $\mathrm{Mg}$ were slightly below the range of sufficiency, while the leaf contents of $\mathrm{S}$ were above the adequate range. Therefore, the nutrient content in leaf tissue did not compromise the adequate corn crop development.

\section{Conclusions}

The $\mathrm{N}$ supply at sowing time provides higher levels of $\mathrm{K}, \mathrm{Ca}, \mathrm{Mg}, \mathrm{Fe}$ and $\mathrm{Zn}$ in leaf tissue, while nitrogen fertilization at the V4 stage provides greater LCI.

The incorporation of urea into the soil provides higher LCI and N, P and K foliar contents.

The increase of $\mathrm{N}$ doses influenced positively the LCI, N, P, S, Cu, Fe, Mn and $\mathrm{Zn}$ foliar contents, and increased corn grain yield up to the dose of $164 \mathrm{~kg} \mathrm{ha}^{-1}$ of $\mathrm{N}$.

The urea application to the surface is more interesting to the incorporated application due to the ease of application, cost, besides propitiating similar corn grain yield.

\section{References}

Arnon, I. (1975). Mineral nutrition of maize (p. 452). Bern: International Potash Institute.

Cantarella, H., Raij, B. van \& Camargo, C. E. O. (1997). In B. van Raij, H. Cantarella, J. A. Quaggio, \& A. M. C. Furlani (Eds.), Recomendações de calagem e adubação para o estado de São Paulo (p. 285). Campinas: Instituto Agronômico de Campinas. Boletim Técnico.

CONAB (Companhia Nacional de Abastecimento). (2017). Acompanhamento de safra brasileira: Grãos, décimo segundo levantamento, Junho/2017 (p. 85). Brasília: CONAB.

Costa, N. R., Andreotti, M., Gameiro, R. A., Pariz, C. M., Buzetti, S., \& Lopes, K. S. M. (2012). Adubação nitrogenada no consórcio de milho com duas espécies de braquiária em sistema plantio direto. Pesquisa Agropecuária Brasileira, 45, 1038-1047. https://doi.org/10.1590/S0100-204X2012000800003

Costa, K. A. P., Faquin, V., Oliveira, I. P., Rodrigues, C., \& Severiano, E. C. (2008). Doses e fontes de nitrogênio em pastagem de capim-marandu. I-alterações nas características químicas do solo. Revista Brasileira de Ciência do Solo, 32, 1591-1599. https://doi.org/10.1590/S0100-06832008000400023

Dathe, A., Postma, J., Postma-Blaauw, M., \& Lynch, J. (2016). Impact of axial root growth angles on nitrogen acquisition in maize depends on environmental conditions. Annals of Botany, 118, 401-414. https://doi.org/ 10.1093/aob/mcw112

Embrapa (Empresa Brasileira de Pesquisa Agropecuária). (2013). Centro Nacional de Pesquisa de Solos. Sistema Brasileiro de Classificação de Solos (3rd ed., p. 353). Brasília, DF: Embrapa.

Espíndula, M. C., Rocha, V. S., Souza, M. A., Campanharo, M., \& Pimentel, A. J. B. (2014). Urease inhibitor (NBPT) and efficiency of single or Split application of urea in wheat crop. Revista Ceres, 61, 273-79. https://doi.org/10.1590/S0034-737X2014000200016

Ferreira, D. F. (2011). Sisvar: A computer statistical analysis system. Ciência e Agrotecnologia, 35, 1039-1042. https://doi.org/10.1590/S1413-70542011000600001

Galindo, F. S., Teixeira Filho, M. C. M., Buzetti, S., Santini, J. M. K., Alves, C. J., \& Ludkiewicz, M. G. Z. (2017). Wheat yield in the Cerrado as affected by nitrogen fertilization and inoculation with Azospirillum 
brasilense. Pesquisa Agropecuária Brasileira, 52, 794-805. https://doi.org/10.1590/s0100-204x201700 0900012

Galindo, F. S., Teixeira Filho, M. C. M., Buzetti, S., Santini, J. M. K., Alves, C. J., Nogueira, L. M., ... Bellotte, J. L. M. (2016). Corn yield and foliar diagnosis affected by nitrogen fertilization and inoculation with Azospirillum brasilense. Revista Brasileira de Ciência do Solo, 40, e015036. https://doi.org/10.1590/18069 $657 \mathrm{rbcs} 20150364$

Gazola, R. N., Lovera, L. H., Celestrino, T. S., Dinalli, R. P., Montanari, R., \& Queiroz, H. A. (2017). Variabilidade espacial das concentrações de nutrientes foliares da soja correlacionadas com atributos químicos de um Latossolo Vermelho distroférrico. Revista Ceres, 64, 441-449. https://doi.org/10.1590/ 0034-737x201764040014

Goes, R. J., Rodrigues, R. A. F., Takasu, A. T., \& Arf, O. (2014). Fontes e doses de nitrogênio em cobertura para a cultura do milho em espaçamento reduzido. Revista Agrarian, 7, 257-263.

Kaneko, F. H., Arf, O., Gitti, D. D. C., Arf, M. V., Chioderoli, C. A., \& Kappes, C. (2010). Manejo do solo e do nitrogênio em milho cultivado em espaçamentos reduzido e tradicional. Bragantia, 69, 677-686. https://doi.org/10.1590/S0006-87052010000300020

Kaneko, F. H., Arf, O., Sabundjian, M. T., Ferreira, J. P., Gitti, D. C., Leal, A. J. F., \& Nascimento, V. (2015). Fontes e modos de aplicação de nitrogênio na cultura do milho em sistema plantio direto/sources of nitrogen and modes of application in maize under no tillage crop. Revista Brasileira de Engenharia de Biossistemas, 9, 191-196. https://doi.org/10.18011/bioeng2015v9n2p191-196

Kappes, C., Arf, O., \& Andrade, J. A. C. (2013a). Coberturas vegetais, manejo do solo, doses de nitrogênio e seus efeitos na nutrição mineral e nos atributos agronômicos do milho. Revista Brasileira de Ciência do Solo, 37, 1322-1333. https://doi.org/10.1590/S0100-06832013000500021

Kappes, C., Arf, O., \& Andrade, J. A. C. (2013b). Produtividade do milho em condições de diferentes manejos do solo e de doses de nitrogênio. Revista Brasileira de Ciência do Solo, 37, 1310-1321. https://doi.org/ $10.1590 / \mathrm{S} 0100-06832013000500020$

Kappes, C., Arf, O., Dal Bem, E. A., Portugal, J. R., \& Gonzaga, A. R. (2014). Manejo do nitrogênio em cobertura na cultura do milho em sistema plantio direto. Revista Brasileira de Milho e Sorgo, 13, 201-217. https://doi.org/10.18512/1980-6477/rbms.v13n2p201-217

Lara Cabezas, W. A. R., Trivelin, P. C. O., Korndorfer, G. H., \& Pereira, S. (2000). Balanço nitrogenado da adubação sólida e fluida de cobertura na cultura de milho em sistema plantio direto. Revista Brasileira de Ciência do Solo, 24, 363-376. https://doi.org/10.1590/S0100-06832000000200014

Liu, Z., Zhu, K., Dong, S., Liu, P., Zhao, B., \& Zhang, J. (2017). Effects of integrated agronomic practices management on root growth and development of summer maize. European Journal of Agronomy, 84, 140-151. https://doi.org/10.1016/j.eja.2016.12.006

Maestrelo, P. R., Buzetti, S., Teixeira Filho, M. C. M., Garcia, C. M. P., Rodrigues, M. A. C., Lino, A. C. M., \& Andreotti, M. (2014). Aplicação de ureia revestida em cobertura no milho irrigado sob sistema de semeadura direta. Revista Brasileira de Ciências Agrárias, 9, 192-199. https://doi.org/10.5039/agraria. v9i2a3708

Malavolta, E., Vitti, G. C., \& Oliveira, S. A. (1997). Avaliação do estado nutricional das plantas: Princípios e aplicações (2nd ed., p. 319). Piracicaba: Potafos.

Marschner, P. (2012). Marschner's mineral nutrition of higher plants (3th ed., p. 651). New York: Academic Press. https://doi.org/10.1016/B978-0-12-384905-2.00015-7

Mota, M. R., Sangoi, L., Schenatto, D. E., Giordani, W., Boniatti, C. M., \& Dall'Igna, L. (2015). Fontes estabilizadas de nitrogênio como alternativa para aumentar o rendimento de grãos e a eficiência de uso do nitrogênio pelo milho. Revista Brasileira de Ciência do Solo, 39, 512-522. https://doi.org/10.1590/010 $00683 \mathrm{rbcs} 20140308$

Nascente, A. S., Kluthcouski, J., Rabela, R. R., Oliveira, P., Cobucci, T., \& Crusciol, C. A. C. (2011). Produtividade do arroz de terras altas em função do manejo do solo e da época de aplicação de nitrogênio. Pesquisa Agropecuária Tropical, 41, 60-65. https://doi.org/10.5216/pat.v41i1.6509

Noor, M. A. (2017). Nitrogen management and regulation for optimum NUE in maize - A mini review. Cogent Food \& Agriculture, 3, 1348214. https://doi.org/10.1080/23311932.2017.1348214 
Nunes, P. H. M. P., Aquino, L. A., Santos, L. P. D. dos, Xavier, F. O., Dezordi, L. R., \& Assunção, N. S. (2015). Produtividade do trigo irrigado submetido à aplicação de nitrogênio e à inoculação com Azospirillum brasilense. Revista Brasileira de Ciência do Solo, 39, 174-182. https://doi.org/10.1590/01000683rbcs 20150354

Raij, B. van, Andrade, J. C., Cantarella, H., \& Quaggio, J. A. (2001). Análise química para avaliação da fertilidade de solos tropicais (p. 285). Campinas: IAC.

Santos, M. M., Galvão, J. C. C., Silva, I. R., Miranda, G. V., \& Finger, F. L. (2010). Épocas de aplicação de nitrogênio em cobertura na cultura do milho em plantio direto, e alocação do nitrogênio $\left({ }^{15} \mathrm{~N}\right)$ na planta. Revista Brasileira de Ciência do Solo, 34, 1185-1194. https://doi.org/10.1590/S0100-06832010000400018

Soratto, R. P., Pereira, M., Costa, T. A. M., \& Lampert, V. N. (2010). Fontes alternativas e doses de nitrogênio no milho safrinha em sucessão à soja. Revista Ciência Agronômica, 41, 511-518. https://doi.org/10.1590/S1806 $-66902010000400002$

Souza, J. A., Buzetti, S., Teixeira Filho, M. C. M., Andreotti, M., Sá, M. E., \& Arf, O. (2011). Adubação nitrogenada na cultura do milho safrinha irrigado em plantio direto. Bragantia, 70, 447-454. https://doi.org/10.1590/S0006-87052011000200028

Sun, X., Ding, Z., Wang, X., Hou, H., Zhou, B., Yue, Y., ... Zhao, M. (2017). Subsoiling practices change root distribution and increase post-anthesis dry matter accumulation and yield in summer maize. Plos One, 12, e0174952. https://doi.org/10.1371/journal.pone.0174952

Teixeira Filho, M. C. M., Buzetti, S., Andreotti, M., Arf, O., \& Benett, C. G. S. (2010). Doses, fontes e épocas de aplicação de nitrogênio em trigo irrigado em plantio direto. Pesquisa Agropecuária Brasileira, 45, 797-804. https://doi.org/10.1590/S0100-204X2010000800004

Teixeira Filho, M. C. M., Buzetti, S., Andreotti, M., Benett, C. G. S., Arf, O., \& Sá, M. E. (2014). Wheat nitrogen fertilization under no till on the low altitude Brazilian Cerrado. Journal of Plant Nutrition, 37, 1732-1748. https://doi.org/10.1080/01904167.2014.889150

Zhou, B., Sun, X., Ding, Z., Ma, W., \& Zhao, M. (2017). Multisplit nitrogen application via drip irrigation improves maize grain yield and nitrogen use efficiency. Crop Science, 57, 1687-1703. https://doi.org/ $10.2135 /$ cropsci2016.07.0623

\section{Copyrights}

Copyright for this article is retained by the author(s), with first publication rights granted to the journal.

This is an open-access article distributed under the terms and conditions of the Creative Commons Attribution license (http://creativecommons.org/licenses/by/4.0/). 